\title{
Risatul Mahid dan Relevansinya Pada Anak Usia Aqil Baliqh
}

\author{
Rizka Amalia1, Uswatun Hasanah² \\ 1Universitas Islam Negeri Sunan Kalijaga Yogyakarta, rizka14rizki@yahoo.co.id \\ 2Universitas Islam Negeri Sunan Kalijaga Yogyakarta, hasanahuswatun751@gmail.com
}

\begin{abstract}
ABSTRAK
Penelitian ini mengkaji seputar materi Fiqhun Al-nisa' dalam kitab Risalatul mahid dan nilai-nilai pendidikan yang diajarkan dan perlu diketahui oleh anakanak usia 'aqil baligh. Tujuan penelitian ini adalah anak-anak lebih dapat memahami dan mampu menerapkan hukum-hukum yang telah diajarkan dalam materi Risalatul Mahid dan memberikan tambahan materi yang belum dibahas dalam muatan pelajaran Fiqih yang ada dalam kurikulum sekolah. Penelitian ini merupakan penelitian studi kasus dengan pendekatan kualitatif deskriptif yang dilakukan di MI Ma'arif Ngrupit Jenangan Ponorogo. Teknik pengumpulan data dari penelitian ini adalah dengan observasi non partisipan, wawancara dan dokumentasi dalam bentuk pengambilan foto saat proses pembelajaran materi risalatul mahid dalam kelas fiqih wanita I dan II. Hasil penelitian menunjukkan bahwa materi fiqhun nisa dalam kitab klasik risalatul mahid karya Abdul hakim muhammad as-samaroni tersebut memiliki tiga bab utama yakni bab haid, istihadloh dan bab nifas. Dengan adanya materi yang spesifik ini yang diajarkan dalam kelas fiqih wanita I dan II khususnya bagi anak-anak usia 'aqil baligh sebagai bekal dan pengetahuan supaya diterapkan dalam kehidupan sehari-harinya.

Kata Kunci:Risalatul mahid, Aqil Baliqh, Pendidikan
\end{abstract}

\begin{abstract}
This study examines the material Fiqhun Al-nisa' in the book Risalatul mahid and the values of education that are taught and need to be known by children of the age of aqil baligh. The purpose of this study is that children are better able to understand and be able to apply the laws that have been taught in the Risalatul Mahid material and provide additional material that has not been discussed in the content of Fiqh in the school curriculum. This research is a case study with a descriptive qualitative approach conducted at MI Ma'arif Ngrupit Jenang Ponorogo. Data collection techniques from this study were nonparticipant observation, interviews and documentation in the form of taking photos during the learning process of risalatul mahid material in fiqh classes for women I and II. The results showed that the fiqhun nisa material in the classic book risalatul mahid by Abdul Hakim Muhammad As-samaroni has three main chapters namely the menstrual chapter, istihadloh and the postpartum chapter. With this specific material that is taught in the figh classes of women I and II, especially for children aged 'aqil baligh as provisions and knowledge to be applied in their daily lives.

Keywords:Risalatul mahid, Aqil Baliqh, education
\end{abstract}




\section{Article history:}

Received: 2-8-2019

Revised: $10-2-2020$

Accepted: 11-2-2020

Copyright (c) 2020 Amalia, Hasanah

\section{PENDAHULUAN}

Perkembangan anak pada usia 'aqil baligh yang merupakan periode sensitif dan memiliki pegaruh yang besar terhadap psikologis anak (suryabrata, 2001:182). Pada tahap ini anak laki-laki dan perempuan akan mengalami tanda yang berbeda. Khususnya bagi perempuan yang mengalami haid atau menstruasi (Hasan, 2006:109). Bagi beberapa anak perempuan yang baru memasuki usia 'aqil baligh dan mengalami haid adakalanya sulit untuk menerima dan merasakan perubahan yang terjadi padanya sehingga terkadang banyak menimbulkan persoalan (Santrock, 2003:97).

Hal ini sering terjadi dikarenakan dua hal yakni anak kurang memiliki pengetahuan awal yang cukup mengenai salah satu tanda perubahan dalam 'aqil baligh yakni haid/menstruasi, dan kurangnya perhatian serta pengetahuan orang tua dalam memperhatikan anak-anaknya. Sehingga beberapa anak akan memiliki perasaan marah, takut, malu, minder, dan jijik ketika mulai haid/menstruasi sehingga menimbulkan keresahan pada anak (Ibrahim, 2005:75.

Sebenarnya hal tersebut merupakan hal yang wajar dan alami bagi mereka.

Sebagaimana fenomena tersebut, kiranya penting bagi orang tua dan guru serta orang dewasa lainnya untuk memberikan pengarahan dan perhatian kepada anak-anak baik usia pra-'aqil baligh ataupun yang sudah memasuki usia 'aqil baligh (Hacket, 1984:7). Sehingga dapat meyakinkan anakanak bahwa hal yang dialami saat itu adalah hal yang wajar, serta dapat dapat memberikan pengarahan mengenai hukum-hukum bagi perempuan yang sedang haid sejak dasar. Hal tersebut penting karena menyangkut mengenai tanggung jawab mereka dalam ibadah seharihari dan tanggung jawab anak kepada diri sendiri.

Berdasarkan latar belakang permasalahan dan uraian di atas 
penelitian ini mengkaji seputar materi Fiqhun Al-nisa' dalam kitab Risalatul mahid dan nilai-nilai pendidikan yang diajarkan dan perlu diketahui oleh anak-anak usia 'aqil baligh. Sehingga anak-anak lebih dapat memahami dan mampu menerapkan hukum-hukum yang telah diajarkan dalam materi Rislatul Mahid dan memberikan tambahan materi yang belum dibahas dalam muatan pelajaran Fiqih yang ada dalam kurikulum sekolah.

\section{METODE}

Penelitian ini merupakan penelitian studi kasus dengan pendekatan kualitatif deskriptif yang dilakukan di MI Ma'arif Ngrupit Jenangan Ponorogo. Penelitian dilakukan terhadap proses pembelajaran dalam kelas fiqih wanita I dan II. Terutama materi fiqhun nisa' yang dipakai dalam acuan pembelajaran. Fiqih wanita I diikuti oleh peserta didik kelas $\mathrm{V}$ dan VI. Sedangkan fiqih wanita II diikuti oleh peserta didik kelas VII dan VII. Untuk menentukan sumber data pada penelitian ini, peneliti menggunakan tehnik Purposive Sampling. Teknik pengumpulan data dari penelitian ini adalah dengan observasi non partisipan, wawancara dan dokumentasi dalam bentuk pengambilan foto saat proses pembelajaran materi risalatul mahid dalam kelas fiqih wanita I dan II. Peneliti menggunakan teknik analisis data dari Miles dan Huberman, yang meliputi reduksi data, penyajian data dan verifikasi.

\section{HASIL DAN PEMBAHASAN}

\section{A. Materi Fiqhun Al-nisa' dalam kitab Risalatul mahid.}

Kitab risalatl mahid yang digunakan dalam penelitian kali ini adalah kitab risalatul mahid karangan Abdul Hakim Muhammad As-sammaroni yang diterbitkan oleh pondok pesantren Al-falah Ploso Kediri Jawa Timur. Materi dalam kitab ini diringkas dengan tujan untuk memudahkan dalam memahami dan membelajarkannya. Karena mengingat wajib untuk mempelajari tentang hukum-hukum haid, istihadhah dan nifas. Serta berbagai permasalahannya (Ahmad, 2008:11). Karena mengatasi permasalahan tersebut sangat erat hubungannya dengan masalah ibadah sehari-hari.

Materi-materi yang terdapat dalam kitab risalatul mahid 
diantaranya; bab haid, bab istihadlah dan bab nifas. Berikut penjelasan di dalamnya;

\section{Bab Haid}

\section{a. Definisi haid}

Definisi haid dalam kitab risalatul mahid ini ialah; darah yang keluar dari farji-nya (kemaluannya) seorang perempuan pada umur haid yakni sembilan tahun qomariyah. Dengan jalan sehat dan darah yang dikeluarkan bukanlah darah rusak (penyakit).

b. Cara menghitung umur baliqh anak

Waktu yang digunakan untuk menghitung umur haid adalah tahun qomariyah atau tahun hijriyahnya, bukah berdasarkan tahun masehi. Dengan ketentuan anak tersebut berumur sembilan tahun kurang lima belas hari. Jika anak perempuan tersebut berumur sembilan tahun kurang enam belas hari atau lebih dan mengeluarkan darah maka itu belum disebut darah haid dan masih tergolong darah rusak (penyakit). Selain itu satu tahun hijriyah ada 354 hari 8 jam dan 48 menit. Sedangkan satu tahun masehi ada 365 hari dan 6 jam tepat. Antara keduanya memiliki perbedaan selisih 10 hari 21 jam dan 12 menit.

\section{c. Sifat dan macam warna darah haid}

Sifat darah haid dibagi menjadi empat macam yakni; kental, berbau, kental sekaligus berbagu, dan tidak kental dan tidak berbau. Sedangkan warna darah dibagi menjadi lima macam yakni; hitam (darah yang kuat), merah, abu-abu (antara merah dan kuning), kuning, dan keruh (kuning dan putih).

\section{d. Tanda- tanda berhentinya darah haid}

Tanda-tanda berhentinya darah haid bisa diketahui dengan dua hal yakni; keluarnya cairan atau lendir putih dan jernih dari rahim (Bali, 2006:136). Keadaan farji kering. Hal ini dapat diketahui dengan cara memasukkan kapan ke dalam farji sampai terkena pada tempat yang tidak terkena basuhan saat istinja'. Atau bagian yang tidak terlihat ketika perempuan duduk jongkok. Bila kapas terlihat putih bersih tidak ada bercak darah warna apapun makan sudah dikatakan selesai waktu haidnya (Ahmad, 2008:27). 


\section{e. Hal- hal yang dilarang ketika haid}

Berikut hal-hal yang dilarang ketika seorang perempuan sedang haid dalam kitab risalatul mahid ini diantaranya; Sholat (baik wajib maupun sunnah), puasa (baik wajib maupun sunnah), membaca Alqur'an, membawa dan menyentuh Alqur'an, berdiam diri di masjid, thawaf, jima' (hubungan suami-istri), istimta' (bersenang-senang antara pusar dan lutut), sujud syukur dan sujud tilawah.

\section{f. Fardhu mandi haid}

Setelah perempuan mengetahui haidnya sudah berhenti, maka wajib melaksanakan mandi besar atau mandi suci yang dimulai dengan; membaca basmalah disertai dengan niat mandi suci dari hadats besar yakni haid. Meratakan air ke seluruh tubuh seperti halnya lipatan-lipatan badan, kerutan-kerutan badan, lubang telinga yang nampak dari luarnya, persendian-persendian badan serta daerah farji saat berjongkok dan masrubah (tempat menutupnya lubang dubur). Selanjutnya yakni tertib atau sesuai dengan urutan-urutannya.

\section{g. Tata cara mengqodho' sholat di waktu datangnya haid dan berhentinya haid.}

Jika seorang perempuan telah selesai haid dalam waktu sholat fardhu dan kira-kira waktunya masih cukup digunakan untuk bersuci dan takbiratul ikhram, maka wajib melaksanakan sholat fardhu pada saat terjentinya haid tersebut.begitu juga dengan sholat sebelumnya jika boleh dijama' dengan sholatya waktu terhentinya tadi. Jadi sholat dzuhur bersama dengan asyar, maghrib dengan isya'. Sedangkan subuh tidak boleh dijama' dengan sholat apapun. Contoh kasusnya; masuk maghrib pukul 17:30, sedangkan jam 17:28 seorang perempuan telah selesai hadinya maka perempuan tersebut wajib mengerjakan sholat apa saja?. Dari contoh tersebut perempuan tersebut wajib menjalankan sholat asyar. Dengan keterangan bahwa perempuan tersebut masih menjumpai waktu asyar meskipun hanya tersisa dua menit dan cukup jika digunakan untuk takbiratul ihram saja. Terlebih lagi jika waktunya masih panjang dan cukup untuk bersuci maka wajib melaksanakan sholat $a d a^{\prime}$ asyar dan qodho' dzuhur. 


\section{Istihadloh}

\section{a. Definisi Istihadloh}

Setiap perempuan yang masuk usia 'aqil baligh dan telah mengalami haid pasti memiliki kebiasaan yang berbeda-beda. Pada dasarnya seorang perempuan juga harus menghitung masa-masa haid dan masa-masa sucinya, mengawasi, mengenali dan memperhatikannya sehingga tidak tercampur dengan darah haid dan darah istikhadlah. Karena keduanya meiliki hukum yang berbeda (Jad, 2009:690).

Istihadlah merupakan darah yang tidak memenuhi syarat haid dan nifas (Mustafa, 2009:141). Istikhadloh merupakan darah yang keluar dari otot-otot rahim bagian bawah atau pada mulut rahim dan sekitarnya, serta keluarnya tidak pada waktu masa-masa haid dan masa-masa nifas. Oleh karena itu istikhadloh juga sering disebut sebagai darah rusak atau penyakit (Mahalli, 2008:104). Sedangkan perempuan yang mengalami istikhadloh disebut juga mustahadlah.

Hukum perempuan yang sedang mengalami istikhadloh berbeda dengan seorang perempuan yang mengalami haid. Para mustahadloh wajib melaksanakan sholat wajib, puasa, membaca Alqur'an dan lain sebagainya. Karena seorang mustahadloh itu dianggap berhadats, maka sebelum melaksanakana sholat fardlu harus melakukan empat perkara yakni:

a) Membasuh farji dengan membersihkannya jika ada sisa darah atau kotoran yang masih melekat.

b) Menyumbat farji dengan kapas atau yang serupa supaya darah tidak menetes keluar ketika melaksanakan sholat.

c) Membalut farji dengan celana dalam atau sejenisnya. Wajib membalut jika dibutuhkan dan selama tidak menimbulkan rasa sakit (Ahmad, 2008:83.

d) Wajib bersuci dengan wudlu atau tayyamum.

Semua perkara tersebut wajib dilakukan setiap akan melaksanakan sholar fardhu dan dilakukan setelah masuk waktu sholat secara tertib dan segera supaya cepat-cepat bisa melaksanakan sholat. Jika tidak segera dilaksanakan maka batal dan wajib mengulangi empat disebabkan oleh ketidakhati-hatian atau 
kelalaian dalam menjalankan empat perkara tersebut.

\section{b. Macam-macam mustahadlah}

Materi dalam risalatul mahid ini membagi mustahadlah menjadi tujuh macam. Hal ini didasarkan pada jenis dan warna darah yang dikeluarkan oleh mustahadlah. Dan berbagai kemungkinan kasus perempuan yang memiliki adat haid dan istihadlah yang berbeda-beda. karena ada perempuan yang sedikit mengeluarkan darah dan terusmenerus mengeluarkan darah bahkan sampai berbulan-bulan. Berikut peneliti sajikan dalam bentuk tabel dibawah ini (AsSamaroni, 1995:28):

Tabel 1

\begin{tabular}{|c|c|c|c|}
\hline $\begin{array}{l}\mathbf{N} \\
\mathbf{0}\end{array}$ & $\begin{array}{c}\text { Nama } \\
\text { Mustahadlah }\end{array}$ & Ket & $\begin{array}{l}\text { Hukum } \\
\text { Haid }\end{array}$ \\
\hline 1 & $\begin{array}{l}\text { Mubtada'ah } \\
\text { mumayyizah }\end{array}$ & $\begin{array}{l}\text { Perempua } \\
\mathrm{n} \text { yang } \\
\text { istihadlah } \\
\text { yang } \\
\text { belum } \\
\text { pernah } \\
\text { haid serta } \\
\text { dapat } \\
\text { membeda } \\
\text { kan warna } \\
\text { dan sifat } \\
\text { darah }\end{array}$ & $\begin{array}{l}\text { Hukum } \\
\text { haidnya } \\
\text { dikembali } \\
\text { kan } \\
\text { kepada } \\
\text { darah } \\
\text { qowi atau } \\
\text { kuat. } \\
\text { Sedangka } \\
\text { n darah } \\
\text { darah dloif } \\
\text { dihukumi } \\
\text { darah } \\
\text { istihadlah. }\end{array}$ \\
\hline 2 & $\begin{array}{l}\text { Mubtada'ah } \\
\text { ghairu } \\
\text { mumayyizah }\end{array}$ & $\begin{array}{l}\text { Perempua } \\
\mathrm{n} \text { yang } \\
\text { belum } \\
\text { pernah } \\
\text { haid, serta } \\
\text { mengeluar } \\
\text { kan darah } \\
\text { hanya } \\
\text { satu } \\
\text { macam }\end{array}$ & $\begin{array}{l}\text { Hukum } \\
\text { haidnya } \\
\text { dikembali } \\
\text { kan } \\
\text { kepada } \\
\text { hukum } \\
\text { paling } \\
\text { sedikitnya } \\
\text { keluarnya } \\
\text { darah }\end{array}$ \\
\hline
\end{tabular}

\section{saja}

misalnya

haid yakni

darah

sehari

merah

atau

hitam

saja.

$3 \quad \begin{aligned} & \text { Mu'tadah } \\ & \text { mumayyizah }\end{aligned}$

Perempua

n

sudah dikembali

pernah kan

haid dan kepada

mengelaur perbedaan

kan darah sifat darah

dua yang

macam dikeluarka

atau lebih. n (qowi

atau dloif).

Bukan

kepada

adat

haidnya.

\begin{tabular}{ll}
\hline 4 & Mu'tadah \\
ghairu & mumayyizah \\
& dzakiratun \\
li'adatiha \\
qadran \\
wawaqtan
\end{tabular}

Perempua Hukum

$n$ yang haid ini

pernah disamaka

haid dan $\mathrm{n}$ dengan

suci serta adat

ingat akan perempua

ukuran, $\mathrm{n}$ tersebut

waktu, haid di

dan suci setiap

yang

bulannya.

menjadi

kebiasaan

haidnya.

5 Mu'tadah Perempua Hukum

ghairu

mumayyizah

nasyiatunli'ad

atiha qadran

wawaqtan

n yang

pernah

haid bagi

haid dan $\mathrm{n}$ ini tidak

suci serta bisa

darah ditentuka

yang n. Karena

dikeluarka seluruh

$\mathrm{n}$ hanya masa

satu mengeluar

macam kan darah

dan dia bisa

tidak ingat mengunda

akan ng banyak

ukuran, kemungki

waktu dan nan haid

adat dan suci.

haidnya. Oleh

karena itu

setian

perempua

$\mathrm{n}$ ini wajib

mandi

ihtiyat 


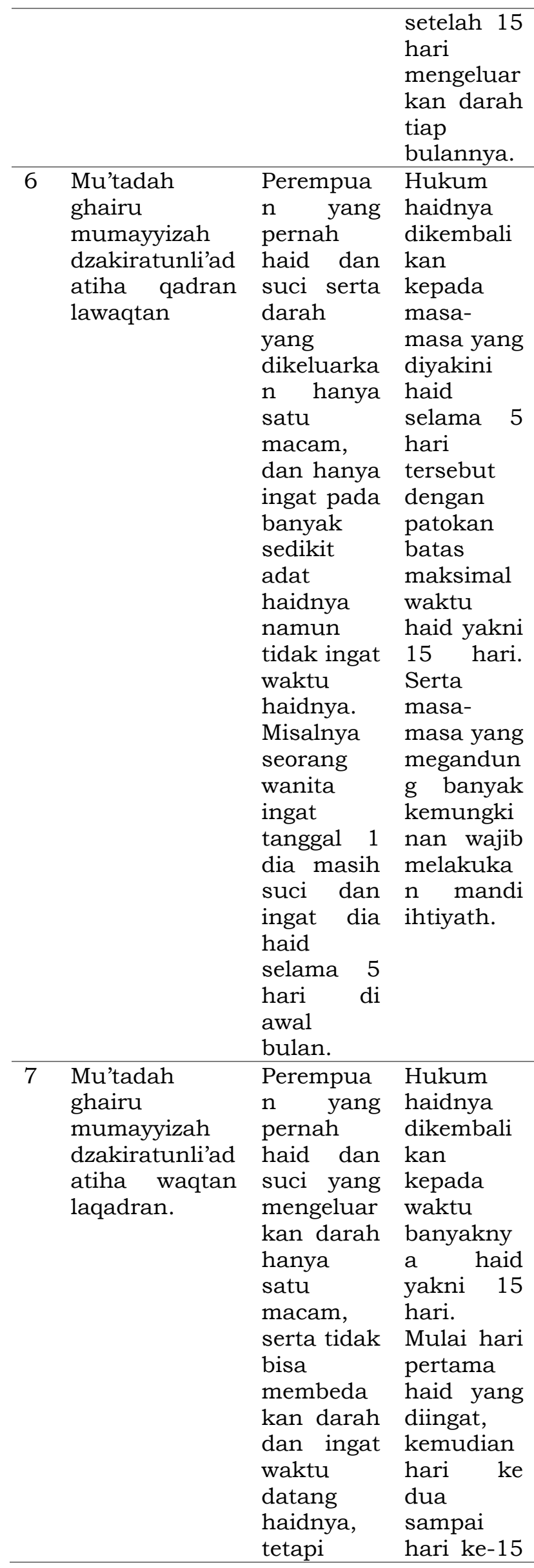

tidak ingat tetap ukuranny dihukumi a/ berapa haid tetapi lama dia wajib haid. mandi ihtiyath.

\section{Nifas}

\section{a. Definisi nifas dan}

\section{ketentuannya}

$\mathrm{Bab}$ nifas dalam risalatul mahid ini dibahas secara mendetal seperti halnya bab haid dan istihadloh. Nifas didefinisikan sebagaimana darah yang keluarkan seorang perempuan setelah melahirkan dengan syarat waktu keluarnya darah tersebut sebelum melewati lima belas hari dari melahirkan (As-Samaroni, 1995:40).

Perempuan yang mengalami nifas berbeda ketentuan massanya dengan perempuan yang sedang haid dan istihadloh. Perempuan memiliki batas paling sedikit mengengeluarkan darah nifas yakni satu tetes. Sedangkan umumnya nifas yakni empat puluh hari dan lamanya nifas yakni enam puluh hari (Mustafa, 2001:35). Oleh karena itu jika nifas melebihi enam puluh hari maka selebihnya dihitung darah isihadloh atau disebut juga istihadloh fin nifas.

Perempuan yang nifas sama pula ketentuannya dengan 
perempuan yang haid seperti halnya; sholat, puasa, memegang Alqur'an, membaca Alqur'an, melakukan sujud tilawah atau syukur dan lain sebagainya. Bagi perempuan yang darah nifasnya masih keluar tidak boleh mandi wiladah, jadi mandi wiladah-nya bersamaan dengan mandi suci karena nifas setelah selesainya nifas atau terhentinya darah nifas (Ahmad, 2008:36).

b. Macam- macam perempuan nifas

Materi nifas dalam risalatul mahid ini membagi Perempuan nifas menjadi empat macam. Pembagian ini didasarkan sebagaimana perempuan yang dijelaskan dalam bab istihadloh. Berikut peneliti sajikan dalam rigkasan tabel berikut ini:

Tabel 2

\begin{tabular}{|c|c|c|c|}
\hline No & $\begin{array}{c}\text { Jenis } \\
\text { Perempuan } \\
\text { Nifas }\end{array}$ & Ket & $\begin{array}{l}\text { Hukum } \\
\text { Nifas }\end{array}$ \\
\hline 1 & $\begin{array}{l}\text { Mubtada'ah } \\
\text { mumayyizah }\end{array}$ & $\begin{array}{l}\text { Perempu } \\
\text { an yang } \\
\text { baru } \\
\text { pertama } \\
\text { kali nifas } \\
\text { dan bisa } \\
\text { membed } \\
\text { akan } \\
\text { sifat } \\
\text { darah } \\
\text { (kuat } \\
\text { atau } \\
\text { lemah). }\end{array}$ & $\begin{array}{l}\text { Hukum } \\
\text { nifas ini } \\
\text { dikembalik } \\
\text { an kepada } \\
\text { darah } \\
\text { yang kuat, } \\
\text { dengan } \\
\text { ketentuan } \\
\text { darah } \\
\text { kuat tidak } \\
\text { melebihi } \\
15 \text { hari. }\end{array}$ \\
\hline 2 & $\begin{array}{l}\text { Mubtada'ah } \\
\text { ghairu }\end{array}$ & $\begin{array}{l}\text { Perempu } \\
\text { an yang } \\
\text { baru }\end{array}$ & $\begin{array}{l}\text { Hukum } \\
\text { nifasnya } \\
\text { dikembalik }\end{array}$ \\
\hline
\end{tabular}

\section{B. Risatul Mahid dan Relevansinya terhadap Pendidikan Anak Usia 'Aqil Baliqh}

Materi dalam risalatul mahid ini ketika diterapkan dalam materi 
tambahan Pendidikan Agama Islam di MI Ma'arif Ponorogo memiliki beberapa kendalan dan relevansi yang harus dipilah-pilah kembali. Hal ini terjadi karena materi ini dianggap sulit atau rumit bagi beberapa anak-anak yang mengikuti pelajaran tambahan yaitu kelas fiqih wanita I yang diikuti oleh kelas $\mathrm{V}$ (lima) dan VI (enam) MI Ma'arif Ma'arif Ponorogo.

Dalam hasil penelitian ini peneliti sajikan pembahasan mengenai relevansi materi risalatul mahid dan pengajarannya ke dalam materi atau per-bab pembahasan sebagai berikut ini;

a. Bab Haid

Materi dalam bab ini merupakan materi yang wajib dan penting disampaikan seluruhnya kepada anak usia 'aqil baligh seperti anak-anak yang kemungkinan akan atau sudah mengalami menstruasi seperti pada anak-anak usia 9 sampai 12 tahun. Yakni ketika anak mengnjak kelas V (lima) dan VI (enam). Materi dalam risalatul mahid ini sangat membantu dan memberikan pengetahuan tambahan yang spesifik terhadap materi seputar haid. Dengan penyampaian dan pengajaran tersebut anak-anak

lebih siap dan percaya diri menghadapi perubahan yang ada dalam dirinya.

Materi-materi bab haid ini pada umumnya sudah diajarkan dalam buku paket fiqih. Akan tetapi ada beberapa materi yang menyangkut risalatul mahid dan belum diajarkan dalam buku pegangan siswa dalam pelajarn fiqih sebagaimana materi risalatul mahid dalam kitab klasiknya Abdul Hakim Muhammad As-samaroni ini diantaranya; materi cara menghitung umur anak yang sudah masuk usia 'aqil baligh, macam-macam warna dan sifat darah haid yang memiliki arti dan hukum yang brbeda-beda, rukun, niat dan tata cara mandi haid, dan tata cara mengqodho' sholat saat datangnya haid dan selesainya haid.

Materi-materi tersebut penting untuk diajarkan dan difahami oleh para anak-anak yang memasuki usia 'aqil baligh. Terutama mengenali warna dan sifat darah yang ternyata memiliki hukum yang berbeda, serta bagaimana mengenal tanda-tanda sudah berhentinya darah haid serta bersuci yang menjadi syarat sahnya melakukan ibadah fardhu ataupun sunnah. Selain itu juga materi 
mengenai mengqodho' sholat yang harus diajarkan sejak awal karena anak yang sudah 'aqil baligh dan sudah mumayyiz maka sudah dihitung dosanya jika meninggalkan perkara yang wajib (Mahalli, 2003:110).

b. Bab Istihadhoh

Materi dalam bab ini sama hanya dengan materi bab haid yang wajib dan harus diajarkan kepada anak-anak usia 'aqil baligh. Materi ini juga tidak kalah pentingnya. Karena mengingat setiap perempuan memiliki kebiasaan haid yang berbeda-beda. Akan tetapi karena materi istihadlah ini cukup komplek dan spesifik serta belum diajarkan dalam buku siswa fiqih maka dalam kelas fiqih wanita di MI Ma'arif Ponorogo ini belum diberikan seluruhnya.

Tingkat kesulitan materi ini yakni mengenai macam-macam mustahadlah dan ketentuannya yang berbeda-beda. oleh karena itu dalam kelas fiqih wanita I ini macammacam mustahadlah dijarkan sampai pada Mubtada'ah mumayyizah dan Mubtada'ah ghairu mumayyizah. Karena kelas fiqih wanita I ini dikhususkan untuk para anak-anak yang akan memasuki usia haid atau menstruasi maupun yang sudah. Dengan tujuan memberikan mereka bekal dan pengetahuan awal agar lebih percaya diri dan tidak ragu-ragu dan tidak takut dalam mengalaminya.

Sedangkan untuk materi istihadloh lajutan diberikan dalam kelas fiqih wanita II. Yakni dikhususkan dipelajari bagi anakanak yang sudah memasuki usia 'aqil baligh dan sudah haid. Karena materi ini memiliki tingkat kesulitan yang tinggi. Dimana materi ini dihadapkan dengan persoalanpersoalan istihadlah perempuan dan dihitung menggunakan kalender bulan haid dan istihadlah yang sudah disiapkan dalam buku strimin. Meskipun materi ini rumit dan kasusnya jarang terjadi dalam kehidupan anak-anak. akan tetapi materi ini wajib diketahui dan diajarkan sebagai bekal pengetahuan anak-anak jika mengalami persoalan istihadloh tersebut.

c. Bab Nifas

Karena kondisi psikisnya anakanak usia 'aqil baligh cenderung memliki rasa keingintahuan yang tinggi. Menjelaskan bab nifas pasti juga menjelaskan sedikit mengenai reproduksi wanita (Asrori, 2009:68). 
Oleh karenanya dalam bab ini pada kelas fiqih wanita belum diajarkan secara keseluruhan. Pengajaran materi ini diberikah sebatas dasardasar atau garis besarnya saja. Karena mengingat bab nifas juga sedikit komplek meskipun tidak seperti bab istihadlah.

Materi yang diajarkan dalam kelas fiqih wanita I ini diantaranya; definisi, ukuran nifas (masa lama dan sedikitnya nifas). Yang terpenting dalam pengajaran ini adalah anak-anak mampu membedakan antara darah haid, darah istihadloh dan darah nifas. Karena jelas masing-masing memiliki hukum yang berbeda. Materi mengenai klasifikasi perempuan nifas juga disampaikan dalam kelas fiqih wanita II (kelas fiqih wanita lanjutan di ingkat Mts).

\section{KESIMPULAN}

Materi fiqhun nisa dalam kitab klasik risalatul mahid karya Abdul hakim muhammad as-samaroni tersebut memiliki tiga bab utama yakni bab haid, istihadloh dan bab nifas. Pada masing-masing bab diejaskan secara spesifik mengenai ketentuan-ketentuannya dan hukum-hukum untuk ukuran, waktu

dan tata cara mengqodho' sholat terutama bagi perempuan istihadloh. Dengan adanya materi yang spesifik ini maka oleh MI Ma'arif diajarkan dalam kelas fiqih wanita I dan II khususnya bagi anak-anak usia 'aqil baligh sebagai bekal dan pengetahuan supaya diterapkan dalam kehidupan sehari-harinya.

Materi dalam risalatul mahid ini harus dibagi dan diajarkan dalam kelas fiqih wanita I dan kelas fiqih wanita II. Hal tersebut karena materi haid sudah sepenuhnya relevan bagi anak-anak yang akan memasuki atau baru memasuki usia 'aqil baligh. Pada materi istihadlah sudah relevan diberikan kepada kelas fiqih wanita I tetapi belum sepenuhnya karena materi terlalu komplek sehingga dilanjutkan ke kelas fiqih wanita II. Sedangkan bab nifas tidak sepenuhnya diberikan di kelas fiqih wanita I dan hanya bagian dasar dan garis besarnya. Kemudian materi ini dilanjutkan di kelas fiqih wanita II secara lebih mendalam.

\section{DAFTAR PUSTAKA}

Ahmad, Muhammad Ardani bin, Risalah Haid, Surabaya: Almiftah, 2008 
Asrori, Muhammad dan Muhammad Ali, Psikologi Remaja dan Perkembangan Peserta Didik, Jakarta; Bumi Aksara, 2009

As-samaroni, Abdul Hakim Muhammad, Risalatul Mahid, Kediri: Maktabah Al-falah, 1995

Bali, Wahid Abdussalam, Ibadah Salah Kaprah,Terj. Muhammad Darwis Jakarta: Amzah, 2006

Burhan Bungin, Penelitian Kualitatif Komonikasi, Ekonomi, Kebijakan Piblik, dan Ilmu, Jakarta: Kencana, 2017

Desmita, Psikologi Perkembangan Peserta Didik, Bandung: Remaja Rosdakarya, 2012

H Hacket, .H Remmers dan C.G, Memahami Persoalan Remaja, Terj. Zakiyah Darajat Jakarta: Bulan Bintang, 1984

Hartati, Netty, Islam dan Psikologi, Jakarta: Raja Grafindo Persada, 2005

Hasan, Aliah. B. Purwakania, Psikologi Perkembangan Islami, Jakarta: Raja Grafindo Persada, 2006

Ibrahim, Zakaria, Psikologi Wanita, Terj. Ghazi Saloom, Bandung: Pustaka Hidayah, 2005

Jad, Syaikh Ahmad, Fiqih Sunnah Wanita, Terj. Masturi Irham dan Nurhadi, Jakarta: Pustaka AlKautsar, 2009

John W. Santrock, Psikologi Orang Dewasa, Terj. Shinto. B. Adelar dan Sherly Saragih, Jakarta: Erlangga, 2003
Mahalli, Ahmad Mudjab, Haditshadits Ahkam, Jakarta: Raja Grafindo Persada, 2008

Mahalli, Ahmad Mudjab, Haditshaidts Ahkam Riwayat Assyafi'i. jakarta: Raja Grafindo persada, 2003

Misbah Ibnu Zainal Mustafa, Masail An-nisa' Surabaya: Maktabah Sa'id Ibn Nashir An-nabhani, 2009

Muchtaromah, Bayyinatul, Pendidikan Reproduksi bagi Anak Menuju Usia 'Aqil Baligh, Malang: UIN Malang Press, 2008

Purnami, Sri dan Wiji hayati, Psikologi Perkembangan, Yogyakarta: Teras, 2008 Rosdakarya, 2009

Sugiyono, Metoode Penelitian Pendidikan Dengan Pendekatan Kuantitatif, Kualitatif,dan R\&D, Bandung: Alfabeta 2015

Sugiyono, Metode Penelitian Kombinasi"Mixed Methods, Bandung: Alfabeta, 2015

Suryabrata, Sumadi, Psikologi Pendidikan, Jakarta: Raja Grafindo Persada, 2001

Widodo, Nur dan Endang Poerwanti, Perkembangan Peserta Didik, Malang: UMM Press, 2002

Yusuf, Syamsu, Psikologi Perkembangan Anak dan Remaja, Bandung: Remaja 